\title{
MEKANISME PEMBENTUKAN ALAT KELENGKAPAN DPRD KOTA SURABAYA PERIODE 2009-2014
}

\author{
Ubed Bagus Razali \\ Komisi Yudisial Republik Indonesia Penghubung Wilayah Jawa Timur \\ J. Ngagel Jaya Tengah III No. 8 Surabaya 60283 | ubed@komisiyudisial.go.id
}

\begin{abstract}
This article discusses about the Islamic political jurisprudence perspective against the formation mechanisms of formulating DPRD (City Council) of Surabaya for 2009-20I 4 through 3 stages. The first is the inauguration of the members and leaders of DPRD of Surabaya for 2009-2014. The second is the formation of fractions. The formulation of fractions is led by the fraction leader of 2009-2014 which consists of I chair and I vice chairman derived from the two parties who get the most first and second seat. The third is the adoption of the draft regulation rules (rules of procedure) and the establishment of the tools of DPRD of Surabaya for 2009-2014 which consists of a definitive chairman (I chairman and 3 vice chairmen), a council, a commission, a Regional Legislation Board, a budget committee, as well as a honorary board. Within the Islamic political jurisprudence perspective, the formation mechanism of establishing tools of DPRD of Surabaya for 2009-2014 reflects the so called amar ma'ruf nahi munkar because the direct mechanism for setting based on the sequence number of the political parties' seats can prevent money politics and internal conflicts among the fellow legislators in Surabaya.
\end{abstract}

Keywords: Formation, parliament, Islamic political jurisprudence.

\begin{abstract}
Abstrak: Artikel ini membahas tentang tinjauan fiqh siyâsah terhadap mekanisme pembentukan alat kelengkapan tersebut. Alat kelengkapan DPRD Kota Surabaya periode 2009-20I 4 dibentuk melalui 3 tahapan. Pertama, peresmian anggota dan pimpinan sementara DPRD Kota Surabaya periode 2009-2014. Kedua, pembentukan fraksi. Pembentukan Fraksi dipimpin pimpinan sementara DPRD Kota Surabaya periode 2009-20 I 4 yang terdiri atas I orang Ketua serta I orang Wakil Ketua yang berasal dari 2 Partai Politik yang mendapat kursi terbanyak pertama dan kedua. Ketiga, penetapan rancangan peraturan tata tertib (tatib) serta pembentukan alat kelengkapan DPRD
\end{abstract}


Kota Surabaya periode 2009-2014 yang terdiri atas Pimpinan Definitif (I Ketua dan 3 Wakil Ketua), Badan Musyawarah, Komisi, Badan Legislasi Daerah, Badan Anggaran, serta Badan Kehormatan. Dalam perspektif fikih, mekanisme pembentukan alat kelengkapan DPRD Kota Surabaya periode 2009-20I4 itu mencermikan suatu perbuatan amar ma'ruf nahi munkar, karena mekanisme penetapan secara langsung berdasarkan urutan jumlah kursi Partai Politik ini dapat mencegah terjadinya money politics dan konflik internal antar sesama anggota DPRD Kota Surabaya.

Kata Kunci: Pembentukan, alat kelengkapan, DPRD, fikih siyasâh.

\section{Pendahuluan}

Teori demokrasi mengajarkan kepada rakyat untuk terlibat atau berpartisipasi dalam perumusan dan penentuan kebijakan pemerintahan. ${ }^{1}$ Hal itu disebabkan rakyat memiliki kekuasaan untuk menentukan pemimpin, sistem, dan tujuan pemerintahan.

Dalam negara modern seperti sekarang, dimana populasi penduduknya sudah semakin banyak dan luasnya jangkauan wilayah, ialah suatu hal yang tidak mungkin untuk meminta pendapat rakyat secara keseluruhan terhadap jalannya pemerintahan. Kondisi tersebut menyebabkan konsep demokrasi tidak akan dapat dilakukan secara murni. Sehingga, perwakilan dari rakyat secara keseluruhan sangat diperlukan untuk mengawasi jalannya pemerintahan melalui sebuah lembaga perwakilan. $^{2}$

Dalam sistem perwakilan, rakyat ialah pihak yang menyerahkan mandat atau kekuasaan untuk mewakilkan opini, sikap, maupun kepentingannya kepada lembaga perwakilan politik di dalam proses politik dan pemerintahan. ${ }^{3}$ Penyerahan kekuasaan itu dilakukan melalui pemilihan umum atau pemilu. Sehingga pemilu legislatif tahun 2009 lalu dapat diartikan sebagai

\footnotetext{
Arbi Sanit, Perwakilan Politik di Indonesia, (Jakarta: Pustaka Pelajar, 1997), 203.

2 Bambang Cipto, Dewan Perwakilan Rakyat; Dalam Pemerintahan Era Modern dan Industrial, (Jakarta: PT. Raja Grafindo Persada, 1995), 37.

${ }^{3}$ A. M. Fatwa, Melanjutkan Reformasi Membangun Demokrasi Dalam Jejak Langkah Parlemen Indonesia Periode 1999-2004, (Jakarta: PT RajaGrafindo Persada, 2004), 72.
} 
proses penyerahan kekuasaan rakyat kepada calon anggota legislatif atau caleg di beberapa tingkatan, yang meliputi: nasional, regional, dan lokal.

Perubahan sistem ketatanegaraan Negara Kesatuan Republik Indonesia yang terjadi akibat reformasi di tahun 1998, dari sistem sentralistik menjadi desentralistik, menyebabkan peran dan tanggung jawab pemerintah daerah menjadi semakin besar. Sistem desentralistik atau otonomi daerah telah membuat lembaga perwakilan rakyat mengalami perubahan menjadi 3 bentuk, yaitu:

1. Dewan Perwakilan Rakyat Republik Indonesia, yang disingkat DPR RI.

2. Dewan Perwakilan Rakyat Daerah Provinsi, yang disingkat DPRD Provinsi.

3. Dewan Perwakilan Rakyat Daerah Kabupaten atau Kotamadya, yang disingkat DPRD Kabupaten/Kota. ${ }^{4}$

Dalam konteks otonomi daerah, DPRD Kabupaten/Kota memiliki peran yang strategis dalam peningkatan kesejahteraan rakyat daerah yang ada di Kabupaten dan Kotamadya, baik rakyat secara keseluruhan atau hanya sebagian (konstituen). ${ }^{5}$ Guna mengoptimalkan peran itu, DPRD Kabupaten/Kota sebagai salah satu penyelenggara pemerintahan daerah di Kabupaten dan Kotamadya dilengkapi beberapa fungsi yang diatur oleh UUD 1945. Fungsi DPRD Kabupaten/Kota itu meliputi Fungsi Legislasi atau fungsi untuk menyusun peraturan daerah bersama-sama dengan Kepala Daerah, Fungsi Anggaran atau fungsi untuk menyusun maupun menetapkan APBD bersama Pemerintah Daerah, serta Fungsi Pengawasan atau fungsi untuk melakukan kontrol terhadap pelaksanaan Undang-undang, Peraturan Daerah, Keputusan Kepala Daerah tingkat Provinsi.

Fungsi di atas adalah sarana yang dimiliki oleh DPRD Kabupaten/Kota untuk mengakomodasi kepentingan berbagai

\footnotetext{
${ }^{4}$ Selanjutnya akan disebut dengan DPRD Kabupaten/Kota.

${ }^{5}$ Sirajuddin, dkk, Peran dan Fungsi DPRD dalam Dinamika Pemerintahan di Daerah, (t.t.: Setara Press, 2009), 91.
}

\section{$227 \mid \begin{aligned} & \text { al-Daulah } \\ & \text { Vol. 5. no.I. April } 2015\end{aligned}$}


pihak untuk merumuskan arah maupun tujuan pembangunan daerah, yang meliputi pemerintahan, pendidikan, ekonomi, kesehatan dan sebagainya. Agar ketiga fungsi tersebut dapat berjalan dengan baik, maka setiap anggota DPRD Kabupaten/Kota dituntut untuk mengerahkan segala kemampuannya dalam menjalankan tugas, fungsi dan wewenang DPRD Kabupaten/Kota.

Guna mengoptimalkan kemampuan seluruh anggota DPRD Kabupaten/Kota, maka DPRD Kabupaten/Kota dianjurkan untuk membentuk struktur keorganisasian atau yang biasa disebut alat kelengkapan. Alat kelengkapan DPRD Kabupaten/Kota dibentuk ketika awal masa keanggotaan DPRD Kabupaten/Kota, dengan mengikuti petunjuk dari Menteri Dalam Negeri dan peraturan perundang-undangan yang ada. ${ }^{6}$

Susunan alat kelengkapan DPRD Kabupaten/Kota sesuai ketentuan Pasal 353 dan 354 Ayat 1 Undang-undang Nomor 27 Tahun 2009 Tentang MPR, DPR, DPD, dan DPRD, terdiri dari:

1. Pimpinan, yang terdiri atas:

a. 1 orang Ketua dan 3 orang Wakil Ketua untuk DPRD Kabupaten/Kota yang beranggotakan 45 orang sampai dengan 50 orang.

b. 1 orang Ketua dan 2 orang Wakil Ketua untuk DPRD Kabupaten/Kota yang beranggotakan 20 orang sampai dengan 44 orang.

2. Badan Musyawarah.

3. Komisi

4. Badan Legislasi Daerah.

5. Badan Anggaran.

6. Badan Kehormatan.

7. Alat kelengkapan lain yang diperlukan dan dibentuk oleh rapat paripurna. 
Pembentukan alat kelengkapan DPRD Kabupaten/Kota di atas dipimpin oleh pimpinan sementara DPRD Kabupaten/Kota ${ }^{7}$ pada rapat paripurna dengan mengikuti peraturan tata tertib DPRD Kabupaten/Kota. Penyusunan peraturan tata tertib DPRD Kabupaten/Kota itu berpedoman pada Peraturan Pemerintah Nomor 25 Tahun 2004 Tentang Pedoman Penyusunan Tata Tertib DPRD dan Peraturan Pemerintah Nomor 53 Tahun 2005 Tentang Perubahan Peraturan Pemerintah Nomor 25 Tahun 2004.

Dengan mengikuti kedua peraturan di atas, maka pimpinan definitif DPRD Kabupaten/Kota ${ }^{8}$ dipilih oleh anggota DPRD Kabupaten/Kota pada rapat paripurna. Rapat paripurna untuk memilih pimpinan definitif harus dihadiri oleh sedikitnya 2/3 dari seluruh jumlah anggota DPRD Kabupaten/Kota itu dengan mengikuti peraturan tata tertib DPRD Kabupaten/Kota yang sebelumnya telah mendapat persetujuan dari 1/2 jumlah anggota DPRD Kabupaten/Kota yang hadir dalam rapat paripurna. Untuk mendukung proses kelancaran pemilihan pimpinan definitif tersebut, maka pimpinan sementara DPRD Kabupaten/Kota dapat membentuk panitia teknis yang terdiri dari unsur Fraksi. Panitia teknis ditetapkan dengan keputusan pimpinan sementara DPRD Kabupeten/Kota.

Calon pimpinan definitif merupakan anggota DPRD Kabupaten/Kota yang diajukan oleh Fraksi ${ }^{9}$ kepada Pimpinan Sementara DPRD Kabupaten/Kota. Seluruh calon Pimpinan Definitif tersebut kemudian diputuskan melalui musyawarah yang melibatkan seluruh anggota DPRD Kabupaten/Kota. Apabila hal tersebut tidak dapat terpenuhi, maka Pimpinan Definitif DPRD Kabupaten/Kota akan ditentukan melalui mekanisme pemilihan berdasarkan suara terbanyak.

\footnotetext{
${ }^{7}$ Pimpinan sementara DPRD Kabupaten/Kota adalah anggota DPRD Kabupaten/Kota dari partai politik yang memperoleh kursi terbanyak berdasarkan hasil pemilu legislatif.

${ }^{8}$ Selanjutnya akan disebut dengan pimpinan definitif.

${ }^{9}$ Fraksi ialah wadah untuk menghimpun anggota DPRD Kabupaten/Kota berdasarkan kesamaan partai politik yang dapat dibentuk apabila memperoleh 5 kursi.
} 
Calon pimpinan definitif yang mendapatkan suara terbanyak pada pemilihan tersebut akan ditetapkan dengan keputusan DPRD kabupaten/Kota sebagai pimpinan definitif dan disampaikan kepada Gubernur guna mendapatkan peresmian. Pimpinan Definitif yang telah diresmikan Gubernur itu wajib meneruskan proses pembentukan alat kelengkapan DPRD Kabupaten/Kota.

Gubernur mempunyai kewenangan untuk tidak menerima keputusan DPRD Kabupaten/Kota apabila mekanisme pemilihan pimpinan definitif di atas tidak sesuai dengan peraturan perundang-undangan. Meski demikian, Gubernur tidak bisa untuk menetapkan pimpinan definitif DPRD Kabupaten/Kota yang ada didaerahnya tanpa didasarkan hasil musyawarah atau pemilihan yang dilaksanakan oleh anggota DPRD Kabupaten/Kota. Hal ini sesuai dengan prinsip yang di ajarkan Islam di dalam Surat AsySyura Ayat 38, yang artinya: "Dan (bagi) orang-orang yang menerima (mematuhi) seruan Tuhannya dan mendirikan shalat, sedang urusan mereka (diputuskan) dengan musyawarah antara mereka, dan mereka menafkahkan sebagian rizki yang Kami berikan kepada mereka". (Q.S. Asy-Syura: 38). ${ }^{10}$

Mekanisme di atas adalah ketentuan yang harus diperhatikan oleh anggota DPRD Kabupaten/Kota dalam membentuk alat kelengkapan DPRD kabupaten/Kota. Namun pada prakteknya mekanisme itu seringkali dikesampingkan oleh kebanyakan anggota DPRD Kabupaten/Kota dengan maksud untuk dapat memenangkan proses pemilihan dan menjadi Pimpinan Definitif DPRD Kabupaten/Kota. Bahkan, banyak anggota DPRD Kabupaten/Kota yang menggunakan money politics dalam pemilihan Pimpinan Definitif DPRD Kabupaten/Kota tersebut. Sehingga, hal itu menyebabkan terjadinya perpecahan di internal anggota DPRD Kabupaten/Kota.

Dengan didasarkan pada pertimbangan di atas, maka Pemerintah Republik Indonesia melalui Departemen Dalam

10 Departemen Agama Republik Indonesia, Al-Qur'an dan Terjemahnya, (Bandung: PT. Sygma Examedia Arkenleema, 20 I2), 789. 
Negeri atau Mendagri melakukan perubahan terhadap mekanisme pembentukan alat kelengkapan DPRD Kabupaten/Kota periode 2009-2014. Mekanisme pembentukan alat kelengkapan DPRD Kabupaten/Kota pada periode 2009-2014 ini adalah dengan penetapan secara langsung berdasarkan urutan jumlah perolehan kursi Partai Politik yang diperoleh dalam pemilu legislatif 9 April 2009.

Seiring berakhirnya pemilu legislatif 2009, maka lima puluh calon anggota DPRD Kota Surabaya periode 2009-2014 yang terpilih dalam pemilu legislatif pada tanggal 9 April 2009 lalu segera disampaikan oleh Komisi Pemilihan Umum (KPU) Kotamadya Surabaya kepada Gubernur Provinsi Jawa Timur untuk ditetapkan atau diresmikan menjadi anggota DPRD Kota Surabaya periode 2009-2014. Lima puluh anggota DPRD Kota Surabaya periode 2009-2014 yang telah diresmikan Gubernur Provinsi Jawa Timur tersebut kemudian segera membentuk alat kelengkapan DPRD Kota Surabaya periode 2009-2014.

Namun, proses pembentukan alat kelengkapan DPRD Kota Surabaya periode 2009-2014 tersebut tidak berjalan lancar, sebab Gubernur Provinsi Jawa Timur tidak berkenan untuk segera menetapkan susunan alat kelengkapan DPRD Kota Surabaya periode 2009-2014. Hal itu dikarenakan adanya surat Menteri Dalam Negeri Nomor 161/3405/SJ Tentang Pelaksanan Tugas dan Fungsi DPRD Provinsi/Kabupaten/Kota Masa Jabatan 2009-2014 yang menyebutkan bahwa "penetapan rancangan peraturan tata tertib menjadi peraturan tata tertib dilakukan oleh Pimpinan Definitif". Namun, yang terjadi pada proses pembentukan alat DPRD Kota Surabaya periode 2009-2014 ini adalah penetapan rancangan peraturan tata tertib pembentukan alat kelengkapan DPRD Kota Surabaya periode 2009-2014 dilakukan pimpinan sementara. Selain itu, adanya rekomendasi dari salah satu Partai Politik kepada anggotanya di DPRD Kota Surabaya yang berstatus sebagai terdakwa dalam kasus gratifikasi Bus Rapid Transit (BRT) dan Surabaya Sport Center atau SSC senilai 720 juta rupiah untuk

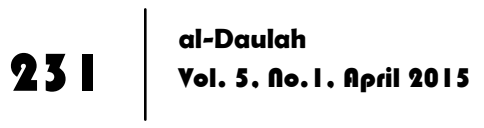


ditetapkan menjadi Pimpinan Definitif DPRD Kota Surabaya periode 2009-2014.

Meskipun demikian, Gubernur Provinsi Jawa Timur pada akhirnya bersedia meresmikan susunan alat kelengkapan DPRD Kota Surabaya periode 2009-2014 itu setelah 3 dari 4 orang calon Pimpinan Definitif Kota Surabaya periode 2009-2014 berjanji kepada Gubernur Provinsi Jawa Timur untuk segera memperbaiki rancangan peraturan tata tertib pembentukan alat kelengkapan DPRD Kota Surabaya periode 2009-2014 sekaligus mengulang kembali proses penetapan rancangan peraturan tata tertib dan segera memproses pemberhentian sementara salah satu Pimpinan Definitif yang sedang menjalani proses hukum tersebut.

Di dalam skripsi ini, penulis berusaha menjelaskan mekanisme pembentukan alat kelengkapan DPRD Kota Surabaya periode 2009-2014 berdasarkan hasil pemilu legislatif tahun 2009 yang kemudian dianlisis dengan pendekatan Fiqh Siyasâh.

\section{Peresmian Anggota dan Penetapan Pimpinan Sementara}

Pemilu legislatif yang diselenggarakan Komisi Pemilihan Umum (KPU) tanggal 9 April 2009 itu bertujuan untuk memilih anggota DPRD Kota Surabaya periode 2009-2014. Calon anggota legislatif DPRD Kota Surabaya itu diajukan 44 Partai Politik peserta pemilu legislatif 2009. Namun, dari hasil rekapitulasi yang dilakukan Komisi Pemilihan Umum (KPU) Kotamadya Surabaya terhadap perolehan suara 44 Partai Politik peserta pemilu itu, hanya 10 Partai Politik yang berhasil memperoleh kursi DPRD Kota Surabaya periode 2009-2014. Kesepuluh Partai Politik itu adalah:

1. Partai Demokrat (PD) dengan 16 kursi.

2. Partai Demokrasi Indonesia Perjuangan Indonesia (PDI-P) dengan 8 kursi.

3. Partai Keadilan Sejahtera (PKS) dengan 5 kursi.

4. Partai Kebangkitan Bangsa (PKB) dengan 5 Kursi.

5. Partai Golongan Karya (Golkar) dengan 5 kursi. 
6. Partai Damai Sejahtera (PDS) dengan 4 kursi.

7. Partai Gerakan Indonesia Raya (Gerindra) dengan 3 kursi.

8. Partai Amanat Nasional (PAN) dengan 2 kursi.

9. Partai Persatuan Pembangunan (PPP) dengan 1 kursi.

10. Partai Kebangkitan Nasional Ulama (PKNU) dengan 1 kursi.

Hasil Rekapitulasi Perolehan Suara

Partai Politik dalam Pemilu Legislatif 2009:

\begin{tabular}{|c|l|c|c|c|}
\hline No & \multicolumn{1}{|c|}{ Nama Partai } & $\begin{array}{c}\text { Perolehan } \\
\text { Suara }\end{array}$ & $\begin{array}{c}\text { Prosentase } \\
\text { (\%) }\end{array}$ & $\begin{array}{c}\text { Perolehan } \\
\text { Kursi }\end{array}$ \\
\hline 1 & $\begin{array}{l}\text { Partai Hati Nurani } \\
\text { Rakyat }\end{array}$ & 23.139 & $2,32 \%$ & 0 \\
\hline 2 & $\begin{array}{l}\text { Partai Karya Peduli } \\
\text { Bangsa }\end{array}$ & 4.553 & $0,46 \%$ & 0 \\
\hline 3 & $\begin{array}{l}\text { Partai Pengusaha Dan } \\
\text { Pekerja Indonesia }\end{array}$ & 2.178 & $0,22 \%$ & 0 \\
\hline 4 & $\begin{array}{l}\text { Partai Peduli Rakyat } \\
\text { Nasional }\end{array}$ & 5.992 & $0,60 \%$ & 0 \\
\hline 5 & $\begin{array}{l}\text { Partai Gerakan } \\
\text { Indonesia Raya }\end{array}$ & 41.560 & $4,17 \%$ & 3 \\
\hline 6 & Partai Barisan Nasional & 956 & $0,10 \%$ & 0 \\
\hline 7 & $\begin{array}{l}\text { Partai Keadilan Dan } \\
\text { Persatuan Indonesia }\end{array}$ & 4.276 & $0,43 \%$ & 0 \\
\hline 8 & Partai Keadilan Sejahtera & 65.358 & $6,57 \%$ & 5 \\
\hline 9 & Partai Amanat Nasional & 53.527 & $5,38 \%$ & 2 \\
\hline 10 & $\begin{array}{l}\text { Partai Perjuangan } \\
\text { Indonesia Baru }\end{array}$ & 0 & $0,00 \%$ & 0 \\
\hline 11 & Partai Kedaulatan & 1.656 & $0,17 \%$ & 0 \\
\hline 12 & Partai Persatuan Daerah & 2.303 & $0,23 \%$ & 0 \\
\hline 13 & $\begin{array}{l}\text { Partai Kebangkitan } \\
\text { Bangsa }\end{array}$ & 64.242 & $6,45 \%$ & 5 \\
\hline 14 & Partai Pemuda Indonesia & 1.547 & $0,16 \%$ & 0 \\
\hline 15 & $\begin{array}{l}\text { Partai Nasional } \\
\text { Indonesia Marhaenisme }\end{array}$ & 710 & $0,07 \%$ & 0 \\
\hline 16 & $\begin{array}{l}\text { Partai Demokrasi } \\
\text { Pembaruan }\end{array}$ & 4.772 & $0,48 \%$ & 0 \\
\hline
\end{tabular}




\begin{tabular}{|c|c|c|c|c|}
\hline 17 & Partai Karya Perjuangan & 597 & $0,06 \%$ & 0 \\
\hline 18 & Partai Matahari Bangsa & 2.375 & $0,24 \%$ & 0 \\
\hline 19 & $\begin{array}{l}\text { Partai Penegak } \\
\text { Demokrasi Indonesia }\end{array}$ & 1.070 & $0,11 \%$ & 0 \\
\hline 20 & $\begin{array}{l}\text { Partai Demokrasi } \\
\text { Kebangsaan }\end{array}$ & 1.431 & $0,14 \%$ & 0 \\
\hline 21 & $\begin{array}{l}\text { Partai Republika } \\
\text { Nusantara }\end{array}$ & 2.883 & $0,29 \%$ & 0 \\
\hline 22 & Partai Pelopor & 1.549 & $0,16 \%$ & 0 \\
\hline 23 & Partai Golongan Karya & 53.549 & $5,38 \%$ & 5 \\
\hline 24 & $\begin{array}{l}\text { Partai Persatuan } \\
\text { Pembangunan }\end{array}$ & 29.600 & $2,97 \%$ & 1 \\
\hline 25 & Partai Damai Sejahtera & 54.960 & $5,52 \%$ & 4 \\
\hline 26 & $\begin{array}{l}\text { Partai Nasional Benteng } \\
\text { Kerakyatan Indonesia }\end{array}$ & 6.278 & $0,63 \%$ & 0 \\
\hline 27 & Partai Bulan Bintang & 3.581 & $0,36 \%$ & 0 \\
\hline 28 & $\begin{array}{l}\text { Partai Demokrasi } \\
\text { Indonesia Perjuangan }\end{array}$ & 189.010 & $18,99 \%$ & 8 \\
\hline 29 & Partai Bintang Reformasi & 4.343 & $0,44 \%$ & 0 \\
\hline 30 & Partai Patriot & 16.216 & $1,63 \%$ & 0 \\
\hline 31 & Partai Demokrat & 311.792 & $31,32 \%$ & 16 \\
\hline 32 & $\begin{array}{l}\text { Partai Kasih Demokrasi } \\
\text { Indonesia }\end{array}$ & 5.613 & $0,56 \%$ & 0 \\
\hline 33 & $\begin{array}{l}\text { Partai Indonesia } \\
\text { Sejahtera }\end{array}$ & 1.356 & $0,14 \%$ & 0 \\
\hline 34 I & $\begin{array}{l}\text { Partai Kebangkitan } \\
\text { Nasional Ulama }\end{array}$ & 23.686 & $2,38 \%$ & 1 \\
\hline $41 \mathrm{I}$ & Partai Merdeka & 2.216 & $0,22 \%$ & 0 \\
\hline 42 & $\begin{array}{l}\text { Partai Persatuan } \\
\text { Nahdlatul Ummah } \\
\text { Indonesia }\end{array}$ & 1.876 & $0,19 \%$ & 0 \\
\hline $43 \mathrm{I}$ & Partai Sarikat Indonesia & 1.252 & $0,13 \%$ & 0 \\
\hline $44 \mathrm{I}$ & Partai Buruh & 3.511 & $0,35 \%$ & 0 \\
\hline & TOTAL SUARA SAH & 995.513 & $100,00 \%$ & 50 \\
\hline
\end{tabular}

Berdasarkan hasil rekapitulasi yang dilakukan KPU Kotamadya Surabaya terhadap perolehan suara partai politik dan 
perolehan suara calon anggota DPRD Kota Surabaya periode 20092104 di atas, maka Gubernur Provinsi Jawa Timur pada tanggal 21 Agustus 2009 menerbitkan Surat Keputusan (SK) dengan nomor 171.436/79/011/2009 untuk meresmikan 50 orang anggota DPRD Kota Surabaya periode 2009-2014.

Lima puluh orang anggota DPRD Kota Surabaya yang telah diresmikan Gubernur Provinsi Jawa Timur kemudian ditetapkan dalam pelantikan atau rapat paripurna istimewa ${ }^{11}$ yang dipandu oleh Kepala Pengadilan Negeri Kotamadya Surabaya, I Nyoman Gede Wirya, pada tanggal 24 Agustus 2009. Penetapan itu dimaksudkan untuk mengambil sumpah 50 orang anggota DPRD Kota Surabaya periode 2009-2014 sebelum menjalankan tugas, fungsi, dan wewenang sebagai anggota DPRD Kota Surabaya. ${ }^{12}$

Selain untuk mengambil sumpah 50 orang anggota DPRD Kota Surabaya periode 2009-2014, rapat paripurna istimewa di gedung DPRD Kota Surabaya juga menetapkan pimpinan sementara DPRD Kota Surabaya periode 2009-2014. Pimpinan sementara DPRD Kota Surabaya yang terdiri dari 1 orang Ketua dan 1 orang Wakil Ketua berasal dari Partai Demokrat dan Partai Demokrasi Indonesia Perjuangan (PDIP). Penetapan itu dikarenakan Partai Demokrat (PD) serta Partai Demokrasi Indonesia Perjuangan (PDIP) merupakan partai yang mendapat kursi terbanyak pertama dan kedua di DPRD Kota Surabaya pada periode 2009-2014. Pimpinan sementara DPRD Kota Surabaya yang betugas untuk memimpin rapat selama pimpinan definitif DPRD Kota Surabaya belum ditetapkan, memfasilitasi pembentukan Fraksi, dan menyusun rancangan peraturan tata tertib itu adalah: ${ }^{13}$

1 Ir. Wishnu Wardhana, SE, MM dari Partai Demokrat (PD) sebagai Ketua.

\footnotetext{
"' Rapat paripurna istimewa ialah istilah lain pelantikan anggota DPRD Provinsi/Kabupaten/Kota.

${ }^{12}$ www.dprdsurabaya.go.id, 28 Februari 2010.

$13 \mathrm{lbid}$.
} 
2 Whisnu Sakti Buana, ST dari Partai Demokrasi Indonesia Perjuangan (PDIP) sebagai Wakil Ketua.

\section{Pembentukan Fraksi}

Sebelum alat kelengkapan DPRD Kota Surabaya periode 2009-2014 ini dibentuk, maka 50 orang anggota DPRD Kota Surabaya periode 2009-2014 itu terlebih dahulu membentuk Fraksi sebagai wadah untuk berhimpun berdasarkan kesamaan partai politik.

Dalam rapat koordinasi pada tanggal 3 September 2009 disepakati bahwa DPRD Kota Surabaya pada periode 2009-2014 akan membentuk Fraksi dengan jumlah anggota sedikitnya 4 orang. ${ }^{14}$ Dengan didasarkan hal tersebut, maka ada 6 partai politik dapat membentuk Fraksi sendiri. Keenam Partai politik itu adalah Partai Demokrat, Partai Demokrasi Indonesia Perjuangan (PDIP) Partai Keadilan Sejahtera (PKS), Partai Kebangkitan Bangsa (PKB), Partai Golkar, dan Partai Damai Sejahtera (PDS). Sedangkan, partai politik yang anggotanya kurang dari 4 orang, yakni Partai Gerakan Indonesia Raya (Gerindra), Partai Amanat Nasional (PAN), Partai Persatuan Pembangunan (PPP), dan Partai Kebangkitan Nasional Ulama (PKNU) bergabung menjadi 1 dengan membentuk Fraksi Gabungan.

Sehingga, pada periode 2009-2014 ini DPRD Kota Surabaya memiliki 7 Fraksi, yang meliputi Fraksi Partai Demokrat, Fraksi Partai Demokrasi Indonesia Perjuangan (F.PDIP), Fraksi Partai Kebangkitan Bangsa (F.PKB), Fraksi Partai Keadilan Sejahtera (F.PKS), Fraksi Partai Golongan Karya (F.PG), Fraksi Partai Damai Sejahtera (F.PDS), serta Fraksi Amanat Persatuan Kebangkitan Indonesia Raya (F.Apkindo). ${ }^{15}$

Struktur keanggotaan masing-masing Fraksi di atas disusun oleh anggota Fraksi itu sendiri. Hasil penyusunan struktur Fraksi

\footnotetext{
14 Irwanto Limantoro, Ketua Fraksi Demokrat DPRD Kota Surabaya periode 2009-2014, Wawancara, 18 Januari 2010 pukul 09.00 WIB di ruang Fraksi Demokrat.

15 Fraksi Apkindo merupakan Fraksi gabungan dari Partai Gerindra, PAN, PPP, dan PKNU.
}

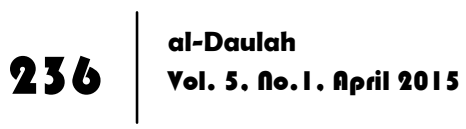


tersebut kemudian ditetapkan oleh pimpinan sementara DPRD Kota Surabaya dengan surat keputusan atau SK pimpinan sementara DPRD Kota Surabaya Nomor 172/857/436.5/2009. Susunan Fraksi tersebut kemudian diumumkan pada rapat paripurna tanggal 4 September 2009. Susunan Fraksi tersebut ialah sebagaimana berikut: ${ }^{16}$

1. Susunan struktur keanggotaan Fraksi Partai Demokrat (F.PD):

Penasehat

Ketua

Wakil Ketua

Sekretaris

Bendahara

Anggota
: Ir. Wishnu Wardhana, SE, MM.

: Irwanto Limantoro.

: Dr. Ratih Retnowati, Dra., M.Si.

: H. Junaedi, SE.

: Ernawati, S.Sos.

: 1. Drs. Sachiroel Alim Anwar.

2. Kartika Pratiwi Damayanti.

3. Herlina Harsono Njoto, S.Psi.

4. Ninuk Irmawati Siwi Pratiwi.

5. Agus Santoso, SH.

6. Soebiantoro, $\mathrm{SH}$.

7. Ivy Juana, S.Sos.

8. Ir. Rusli Yusuf, MT.

9. Mochamad Anwar, SH, M.Si.

10.Moch. Machmud, S.Sos.

11.Ine Listiyani, $\mathrm{SH}$.

2. Susunan struktur keanggotaan Fraksi Partai Demokrasi Indonesia Perjuangan (F.PDIP):

Penasehat : Whisnu Sakti Buana, ST.

Ketua : Baktiono, BA.

Wakil Ketua : Ir. H. Armuji, MH.

Sekretaris : : Tri Didik Adiono, S.Sos.

Bendahara : Syaifuddin Zuhri.

Anggota $\quad: 1$. H. Rizkie Darma Putra, S.Sos.

2. Hj. Agustin Poliana, $\mathrm{SH}$.

${ }^{16}$ Hasil mencatat risalah rapat paripurna di ruang sekretariat DPRD Kota Surabaya pada tanggal 5 April 2010 pukul 09.00 WIB. 
3. Hj. Khusnul Khotimah, S.Pd.

3. Susunan struktur keanggotaan Fraksi Partai Keadilan Sejahtera (F.PKS):

Ketua : Fatkur Rohman, ST, MT.

Wakil Ketua

: Tri Setijo Puruwito, S.Si.

Sekretaris

: Alfan Khusaeri, ST.

Bendahara

: Reni Astuti, S.Si.

Anggota

: Akhmad Suyanto, ST, MT.

4. Susunan struktur keanggotaan Fraksi Partai Kebangkitan Bangsa (F.PKB):

Ketua

: KH. Moch. Na'im Ridwan, SH, MH.

Wakil Ketua

: Ir. H. Masduki Toha.

Sekretaris

: Mazlan Mansur, SE.

Anggota

: 1. Drs. H. Musyafak Rouf, MH.

2. Musrifah, SE.

5. Susunan struktur keanggotaan Fraksi Partai Golkar (F.PG):

Penasehat

: 1. Drs. Eddi Budi Prabowo, Apt, M.Si.

2. Erick Reginal Tahalele, S.Sos.

Ketua

: Ir. Adies Kadir, SH, M.Hum.

Wakil Ketua

: Agus Sudarsono

Sekretaris

: Blegur Prijanggono, SH.

6. Susunan struktur keanggotaan Fraksi Partai Damai Sejahtera (F.PDS):

Ketua : Simon Lekatompessy.

Wakil Ketua

: Pdm. Rio Pattiselano, S.Kom.

Sekretaris

: Imanuel Fredik Lumaindong.

Bendahara

: Dra. Sudarwati Rorong, MM.

7. Susunan struktur keanggotaan Fraksi Gabungan dengan nama Fraksi Amanat Persatuan Kebangkitan Indonesia Raya (F.Apkindo):

Penasehat

: Ir. H. Sudirdjo (PAN)

Ketua

: H. Eddy Rusianto, SH, MH. (Gerindra)

Wakil Ketua

: H. Saiful Bahri, S.Ag (PPP)

Sekretaris

: Camelia Habiba (PKNU) 


$\begin{array}{ll}\text { Bendahara } & \text { : Dra. Yayuk Puji Rahayu (Gerindra) } \\ \text { Anggota } & : 1 . \text { Hj. Luthfiyah, S.Psi. (Gerindra) } \\ & \text { 2. Hafid Su'adi, SH. (PAN) }\end{array}$

Fraksi Partai Demokrasi Indonesia Perjuangan atau F.PDIP pada tanggal 8 Oktober 2009 mengajukan perubahan struktur. Hasil perubahan struktur Fraksi Partai Demokrasi Indonesia Perjuangan (F.PDIP) itu kemudian ditetapkan dalam surat keputusan DPRD Kota Surabaya Nomor 172/882/436.5/2009. Sehingga, susunan Fraksi Partai Demokrasi Indonesia Perjuangan (F.PDIP) saat ini ialah: ${ }^{17}$

Penasehat

: Whisnu Sakti Buana, ST.

Ketua

: Syaifuddin Zuhri.

Wakil Ketua

: Ir. H. Armuji, MH.

Sekretaris

: Hj. Agustin Poliana, SH.

Bendahara

: Hj. Khusnul Khotimah, S.Pd.

Anggota

: 1. H. Rizkie Darma Putra, S.Sos.

2. Baktiono, BA.

3. Tri Didik Adiono, S.Sos.

Sedangkan, pada tanggal 5 April 2010 giliran Fraksi Partai Golkar (F.PG) mengajukan perubahan struktur Fraksi, yang kemudian ditetapkan di dalam Surat Keputusan DPRD Kota Surabaya Nomor 172/361/436.5/2010. Sehingga struktur Fraksi Golkar (F.PG) saat ini adalah: ${ }^{18}$
Penasehat
: 1. Drs. Eddi Budi Prabowo, Apt, M.Si.
2. Ir. Adies Kadir, SH, M.Hum.
Ketua
: Blegur Prijanggono, SH.
Wakil Ketua
: Agus Sudarsono
Sekretaris
: Erick Reginal Tahalele, S.Sos. 


\section{Pembentukan dan Penetapan Alat Kelengkapan DPRD Kota Surabaya Periode 2009-2014}

Pembentukan alat kelengkapan DPRD Kota Surabaya periode 2009-2014 dalam rapat paripurna pada tanggal 11 September 2009 tidak berjalan lancar. Hal tersebut disebabkan oleh aksi walk out yang dilakukan Fraksi Partai Kebangkitan Bangsa (F.PKB), Fraksi Partai Golkar (F.PG), serta Fraksi Gabungan atau Fraksi Amanat Persatuan Kebangkitan Indonesia Raya (F.Apkindo).

Dalam rapat paripurna yang dimaksudkan untuk mengesahkan rancangan tata tertib dan membentuk alat kelengkapan DPRD Kota Surabaya 2009-2014 itu Fraksi Partai Kebangkitan Bangsa dan Fraksi Partai Golkar mengusulkan supaya panitia teknis ${ }^{19}$ dibentuk ulang dalam rapat paripurna. Namun, usul kedua Fraksi itu ditolak oleh pimpinan sementara DPRD Kota Surabaya karena panitia teknis bukan termasuk alat kelengkapan DPRD, sehingga pembentukannya tidak harus dilakukan pada rapat paripurna. Sedangkan, Fraksi Apkindo menuntut agar rapat paripurna itu ditunda guna memberikan kesempatan kepada anggota DPRD Kota Surabaya untuk memperlajari terlebih dahulu rancangan peraturan tata tertib atau tatib yang akan digunakan sebagai pijakan pembentukan alat kelengkapan DPRD Kota Surabaya periode 2009-2014. ${ }^{20}$ Usul Fraksi Amanat Persatuan Kebangkitan Indonesia Raya tersebut juga ditolak pimpinan sementara DPRD Kota Surabaya karena dapat memperlambat proses pembentukan alat kelengkapan DPRD Kota Surabaya. Meski demikian, rapat paripurna tetap dilanjutkan dengan menetapkan peraturan tata tertib (tatib) pembentukan alat kelengkapan DPRD Kota Surabaya 2009-2014. Hal tersebut dikarenakan rapat paripurna masih kuorum atau

\footnotetext{
${ }^{19}$ Sebutan untuk utusan seluruh Fraksi yang bertugas mewujudkan rapat paripurna pembentukan alat kelengkapan DPRD Kota Surabaya periode 2009-20I4.

${ }^{20}$ Jawa Pos, 12 September 2009, 43
} 
diikuti lebih dari $1 \frac{1}{2}$ jumlah seluruh anggota DPRD Kota Surabaya periode 2009-2014. ${ }^{21}$

Dengan didasarkan pada Undang-undang Nomor 27 Tahun 2009 Tentang MPR, DPR, DPD, dan DPRD Pasal 354 Ayat 2, yang berbunyi: pimpinan DPRD Kabupaten/Kota berasal dari partai politik berdasarkan urutan perolehan kursi terbanyak di DPRD Kabupaten/Kota, maka Ketua DPRD Kota Surabaya periode 2009-2014 berasal dari partai politik yang mendapatkan kursi terbanyak pertama, yaitu Partai Demokrat. Sedangkan, 3 Wakil Ketua DPRD Kota Surabaya periode 2009-2014 berasal dari 3 partai politik yang memperoleh kursi terbanyak kedua, ketiga, dan keempat. Partai Demokrasi Indonesia Perjuangan atau PDIP sebagai partai politik yang mendapatkan kursi terbanyak di urutan kedua dengan 8 kursi berhak untuk mendudukkan salah satu anggotanya menjadi Wakil Ketua DPRD Kota Surabaya periode 2009-2014. Karena terdapat 3 patai politik yang sama-sama menempati urutan ketiga dalam perolehan kursi terbanyak di DPRD Kota Surabaya pada periode 2009-2014, yaitu Partai Keadilan Sejahtera (PKS), Partai kebangkitan Bangsa (PKB), dan Partai Golkar, maka penentuan untuk jabatan 2 Wakil Ketua DPRD Kota Surabaya didasarkan pada perolehan hasil suara ketiga partai politik itu pada pemilu legislatif 9 April 2009 lalu. Dengan mengikuti hasil perolehan suara ketiga partai politik tersebut dalam pemilu legislatif 2009, maka PKS dan PKB dinyatakan sebagai partai politik yang mendapat kursi terbanyak di urutan ketiga dan keempat. Sehingga, kedua partai itu (PKS dan PKB) berhak mendudukkan anggotanya menjadi Wakil Ketua DPRD Kota Surabaya periode 2009-2014..$^{22}$ Sedangkan komposisi anggota alat kelengkapan yang lain, seperti: Badan Musyawarah, Komisi, Badan Legislasi Daerah, Badan Anggaran, serta Badan Kehormatan didasarkan kepada

21 Irwanto Limantoro, Ketua Fraksi Demokrat DPRD Kota Surabaya periode 2009-20I4, Wawancara, 18 Januari 2010 pukul 09.00 WIB di ruang Fraksi Demokrat.

22 Ibid. 
jumlah anggota masing-masing Fraksi.23 Komposisi alat kelengkapan tersebut adalah sebagai berikut: ${ }^{24}$

1. Pimpinan, terdiri dari 1 orang Ketua dan 3 orang Wakil Ketua dengan rincian sebagai berikut:
a. Ketua
: Fraksi Partai Demokrat (F.PD).
b. Wakil Ketua: Fraksi Partai Demokrasi Indonesia Perjuangan (F.PDIP).
c. Wakil Ketua : Fraksi Partai Keadilan Sejahtera (F.PKS).
d. Wakil Ketua : Fraksi Partai Kebangkitan Bangsa (F.PKB).

2. Badan Musyawarah (Banmus), terdiri dari 23 anggota utusan Fraksi dengan rincian sebagai berikut:
a. Fraksi Partai Demokrat (F.PD) :8 anggota.
b. Fraksi Partai Demokrasi Indonesia Perjuangan (F.PDIP) : 4 anggota.
c. Fraksi Partai Keadilan Sejahtera (F.PKS): 2 anggota.
d. Fraksi Partai Kebangkitan Bangsa (F.PKB): 2 anggota.
e. Fraksi Partai Golongan Karya (F.PG) : 2 anggota.
f. Fraksi Partai Damai Sejahtera (F.PDS) $: 2$ anggota.
g. Fraksi Amanat Persatuan Kebangkitan Indonesia Raya: 3 anggota.

3. Komisi, terdiri dari 4 bidang dengan rincian sebagai berikut:
a. Komisi A : Bidang Pemerintahan, berjumlah 12 anggota.
b. Komisi B : Bidang Perekonomian, berjumlah 11 anggota.
c. Komisi C : Bidang Pembangunan, berjumlah 11 anggota.
d. Komisi D : Bidang Kesejahteraan Rakyat, berjumlah 11 anggota.

4. Badan Legislasi Daerah (Banlegsda), terdiri dari 13 anggota utusan Fraksi dengan rincian sebagai berikut:
a. Fraksi Partai Demokrat (F.PD): 4 anggota.
b. Fraksi Partai Demokrasi Indonesia Perjuangan (F.PDIP): 3 anggota.

\footnotetext{
${ }^{23}$ Eka Naila Hanik, SH (Kepala Sub Bagian rapat dan Risalah DPRD Kota Surabaya), Wawancara, 5 April 2010 pukul 09.00 WIB di Sekretariat DPRD Kota Surabaya.

${ }^{24}$ Jawa Pos, 10 September 2009, 29-39.
} 
c. Fraksi Partai Keadilan Sejahtera (F.PKS): 1 anggota.

d. Fraksi Partai Kebangkitan Bangsa (F.PKB): 1 anggota.

e. Fraksi Partai Golongan Karya (F.PG): 1 anggota.

f. Fraksi Partai Damai Sejahtera (F.PDS): 1 anggota.

g. Fraksi Amanat Persatuan Kebangkitan Indonesia Raya: 2 anggota.

5. Badan Anggaran (Banggar), terdiri dari 23 anggota utusan Fraksi dengan rincian sebagai berikut:

a. Fraksi Partai Demokrat (F.PD): 8 anggota.

b. Fraksi Partai Demokrasi Indonesia Perjuangan (F.PDIP): 4 anggota.

c. Fraksi Partai Keadilan Sejahtera (F.PKS): 2 anggota.

d. Fraksi Partai Kebangkitan Bangsa (F.PKB): 2 anggota.

e. Fraksi Partai Golongan Karya (F.PG): 2 anggota.

f. Fraksi Partai Damai Sejahtera (F.PDS): 2 anggota.

g. Fraksi Amanat Persatuan Kebangkitan Indonesia Raya: 3 anggota.

6. Badan Kehormatan (BK), terdiri dari 7 anggota utusan Fraksi dengan rincian sebagai berikut:

a. Fraksi Partai Demokrat (F.PD): 1 anggota.

b. Fraksi Partai Demokrasi Indonesia Perjuangan (F.PDIP): 1 anggota.

c. Fraksi Partai Keadilan Sejahtera (F.PKS) : 1 anggota.

d. Fraksi Partai Kebangkitan Bangsa (F.PKB): 1 anggota.

e. Fraksi Partai Golongan Karya (F.PG): 1 anggota.

f. Fraksi Partai Damai Sejahtera (F.PDS): 1 anggota.

g. Fraksi Amanat Persatuan Kebangkitan Indonesia Raya: 1 anggota.

Pada tanggal 15 September 2009 rapat paripurna kembali diadakan untuk menetapkan pimpinan definitif dan membentuk alat kelengkapan lainnya dengan komposisi di atas. Pembentukan alat kelengkapan DPRD Kota Surabaya tersebut dipimpin oleh pimpinan sementara DPRD Kota Surabaya dengan mengacu pada peraturan tata tertib yang telah disahkan pada rapat paripurna 
sebelumnya. Untuk pimpinan Badan Musyawarah dan Badan Anggaran secara otomatis dijabat oleh pimpinan definitif DPRD Kota Surabaya. Sedangkan, pimpinan Komisi, Badan Legislasi Daerah, serta Badan Kehormatan dipilih anggota alat kelengkapan itu sendiri dengan sistem paket. Paket calon pimpinan ketiga alat kelengkapan, yang meliputi Ketua, Wakil Ketua, serta Sekretaris tersebut adalah hasil lobi pimpinan seluruh Fraksi. ${ }^{25}$

Hasil pembentukan alat kelengkapan DPRD Kota Surabaya itu kemudian disampaikan kepada Gubernur Provinsi Jawa Timur untuk mendapat pesermian. Namun alat kelengkapan DPRD Kota Surabaya periode 2009-2014 tersebut tidak langsung diresmikan, sebab Gubernur ingin berkonsultasi terlebih dahulu dengan Biro Hukum Pemerintah Provinsi Jawa Timur mengenai peraturan tata tertib dan hasil pembentukan alat kelengkapan DPRD Kota Surabaya.26 Hal ini disebabkan belum adanya Peraturan Pemerintah yang baru mengenai Pedoman Penyusunan Peraturan Tata Tertib DPRD dan instruksi dari Menteri Dalam Negeri. ${ }^{27}$

Tanggal 25 September 2009 pimpinan sementara DPRD Kota Surabaya dipanggil oleh Gubernur Provinsi Jawa Timur. Hal tersebut dikarenakan adanya surat dari Menteri Dalam Negeri Nomor 161/3405/SJ tentang Pelaksanaan Tugas dan Fungsi DPRD Provinsi/Kabupaten/Kota Masa Jabatan 2009-2014. Di dalam pertemuan yang juga diikuti 16 orang anggota DPRD Kota Surabaya dari Fraksi Partai Demokrat itu Gubernur meminta agar peraturan tata tertib beserta susunan alat kelengkapan DPRD Kota Surabaya periode 2009-2014 tersebut diperbaiki dan ditetapkan ulang dalam rapat paripurna DPRD Kota Surabaya yang dipimpin Pimpinan Definitif. ${ }^{28}$ Selain itu, Gubernur Provinsi Jawa Timur yang didampingi Asisten I Setdraprov, Kepala Biro Administrasi

\footnotetext{
${ }^{25}$ Jawa Pos, 16 September 2009, 29 dan 39.

${ }^{26}$ Jawa Pos, 17 September 2009, 30.

27 Jawa Pos, 25 September 2009, 22.

${ }^{28}$ Irwanto Limantoro, Ketua Fraksi Demokrat DPRD Kota Surabaya periode 2009-20I4, Wawancara, 18 Januari 2010 pukul 09.00 WIB di ruang Fraksi Demokrat.
} 
Pemerintahan, dan Kepala Biro Hukum Pemerintah Provinsi Jawa Timur juga mengajukan beberapa persyaratan, yang meliputi: ${ }^{29}$

1. Melampirkan surat asli dari Walikota Surabaya tentang permohonan atau usul peresmian pengangkatan pimpinan DPRD Kota Surabaya periode 2009-2014.

2. Melampirkan surat asli dari Ketua Smentara DPRD Kota Surabaya mengenai usul peresmian serta pengangkatan pimpinan DPRD Kota Surabaya masa jabatan 2009-2014.

3. Melampirkan surat keputusan (SK) pimpinan sementara DPRD Kota Surabaya tentang penetapan pimpinan DPRD Kota Surabaya periode 2009-2014.

4. Melampirkan risalah rapat dan berita acara penetapan pimpinan DPRD Kota Surabaya periode 2009-2014.

5. Melampirkan surat dari DPC Partai Politik tentang usul penunjukan pimpinan DPRD Kota Surabaya periode 20092014.

Meski seluruh persyaratan di atas telah dipenuhi, Gubernur Provinsi Jawa Timur sempat ragu untuk meresmikan pimpinan definitif DPRD Kota Surabaya periode 2009-2014. Sebab, salah seorang calon pimpinan definitif yang diajukan oleh Fraksi Partai Kebangkitan Bangsa tengah berstatus sebagai terdakwa dalam kasus gratifikasi bus rapid transit (BRT) dan Surabaya sport center (SSC) senilai 720 juta rupiah. Namun, setelah calon Pimpinan definitif DPRD Kota Surabaya yang lain, meliputi: Ir. Whisnu Wardhana, SE, MM dari Fraksi Partai Demokrat, Whisnu Sakti Buana, ST dari Fraksi PDIP, dan Akhmad Suyanto, ST dari Fraksi PKS, berjanji kepada Gubernur Provinsi Jawa Timur untuk segera memproses pemberhentian sementara salah satu Pimpinan Definitif yang telah diajukan oleh Fraksi PKB tersebut, maka Gubernur Provinsi Jawa Timur berkenan meresmikan pimpinan definitif DPRD Kota Surabaya periode 2009-2014. ${ }^{30}$ Pimpinan definitf DPRD Kota Surabaya periode 2009-2014 tersebut pada

\footnotetext{
${ }^{29}$ Jawa Pos, 27 September 2009, 26.

${ }^{30}$ Jawa Pos, 7 Oktober 2009, 26
}

\section{$245 \mid \begin{aligned} & \text { al-Daulah } \\ & \text { Vol. 5. no.I. April } 2015\end{aligned}$}


akhirnya ditetapkan oleh Gubernur Provinsi Jawa Timur tanggal 5 Oktober 2009 melalui surat keputusan (SK) Nomor 171.436/110/011/2009. ${ }^{31}$

Setelah pimpinan definitif DPRD Kota Surabaya diresmikan, maka pada tanggal 7 Oktober 2009 kembali diadakan rapat paripurna DPRD Kota Surabaya guna mengesahkan kembali rancangan peraturan tata tertib sekaligus membentuk 3 alat kelengkapan, yang terdiri dari Komisi, Badan Legislasi Daerah, dan Badan Kehormatan. Sedangkan, Badan Musyawarah beserta Badan Anggaran dibentuk dalam rapat paripurna tanggal 8 Oktober 2009. Susunan alat kelengkapan adalah:

1. Pimpinan definitif DPRD Kota Surabaya, yang diresmikan oleh Gubernur Provinsi Jawa Timur pada tanggal 5 Oktober 2009 melalui surat keputusan (SK) Nomor 171.436/110/011/2009 adalah sebagai berikut: ${ }^{32}$

Ketua : Ir. Wishnu Wardhana, SE, MM (Fraksi Demokrat)

Wakil Ketua: Whisnu Sakti Buana, ST (Fraksi PDIP)

Wakil Ketua: Akhmad Suyanto, ST, MT (Fraksi PKS)

Wakil Ketua: Drs. H. Musyafak Rouf, MH (Fraksi PKB)

2. Susunan Komisi DPRD Kota Surabaya, yang dibentuk pada 7 Oktober 2009 serta ditetapkan oleh pimpinan definitif dalam surat keputusan (SK) DPRD Kota Surabaya Nomor 50 Tahun 2009, terdiri dari: ${ }^{33}$
a. Komisi A (Bidang Pemerintahan)
b. Komisi B (Bidang Perekonomian dan Keuangan)
c. Komisi C (Bidang Pembangunan)
d. Komisi D (Bidang Kesejahteraan Rakyat)

3. Susunan Badan Legislasi Daerah DPRD Kota Surabaya, dibentuk pada 7 Oktober 2009 dan ditetapkan oleh

\footnotetext{
${ }^{31}$ Hasil mencatat risalah rapat paripurna di ruang sekretariat DPRD Kota Surabaya pada tanggal 12 April 2010 pukul $09.00 \mathrm{WIB}$.

32 lbid.

${ }^{33}$ Hasil mencatat risalah rapat paripurna di ruang sekretariat DPRD Kota Surabaya pada tanggal I3 April 2010 pukul 09.00 WIB
} 
pimpinan definitif dalam surat keputusan (SK) DPRD Kota Surabaya Nomor 51 Tahun 2009.34

4. Susunan Badan Kehormatan DPRD Kota Surabaya, yang dibentuk pada 7 Oktober 2009 dan ditetapkan oleh pimpinan definitif dalam surat keputusan (SK) DPRD Kota Surabaya Nomor 52 Tahun 2009.35

5. Susunan Badan Musyawarah DPRD Kota Surabaya, yang dibentuk pada 8 Oktober 2009 dan ditetapkan oleh pimpinan definitif dalam surat keputusan (SK) DPRD Kota Surabaya Nomor 53 Tahun 2009.36

6. Susunan Badan Kehormatan DPRD Kota Surabaya, yang dibentuk pada 8 Oktober 2009 dan ditetapkan dalam Surat Keputusan (SK) DPRD Kota Surabaya Nomor 52 Tahun 2009.37

Tinjauan Fiqh Siyasâh terhadap Pembentukan Alat Kelengkapan DPRD Kota Surabaya Periode 2009-2014

Perwakilan politik merupakan hubungan saling mewadahi dan ketergantungan antara rakyat sebagai pemilih dengan calon atau kandidat yang telah memenangkan kursi lembaga perwakilan rakyat sebagai wakil rakyat. Pola hubungan antara rakyat dengan wakil rakyat di dalam sistem perwakilan politik tersebut ialah dengan saling memberi dan saling menerima. ${ }^{38}$

Sebagai upaya untuk menciptakan hubungan perwakilan politik yang baik guna mengoptimalkan tugas, fungsi, dan wewenang DPRD Kota Surabaya periode 2009-2014, maka dibentuklah susunan alat kelengkapan yang terdiri dari unsur: Pimpinan (1 Ketua dan 3 Wakil Ketua), Badan Musyawarah, Komisi, Badan Legislasi Daerah, Badan Anggaran, dan Badan

\footnotetext{
${ }^{34}$ Ibid.

${ }^{35} \mathrm{lbid}$.

${ }^{36}$ Hasil mencatat risalah rapat paripurna di ruang sekretariat DPRD Kota Surabaya pada tanggal I4 April 2010 pukul $09.00 \mathrm{WIB}$

${ }^{37}$ lbid.

${ }^{38}$ Arbi Sanit, Partai, Pemilu, dan Demokrasi, 152.
}

\section{$247 \mid$\begin{tabular}{l|l} 
al-Daulah \\
Vol. 5. no.I. April 2015
\end{tabular}}


Kehormatan dengan mengikuti Undang-undang Nomor 27 Tahun 2009 Tentang MPR, DPR, DPD, dan DPRD. Mekanisme pembentukan alat kelengkapan DPRD Kota Surabaya periode 2009-2014 mengikuti urutan jumlah perolehan kursi partai politik yang didasarkan pada hasil pemilu legislatif 2009.

Alat kelengkapan DPRD Kota Surabaya periode 2009-2014 dibentuk melalui tiga (3) tahapan. Pertama, peresmian anggota dan Pimpinan Sementara DPRD Kota Surabaya periode 2009-2014. Anggota dan Pimpinan Sementara itu diresmikan oleh Gubernur Provinsi Jawa Timur berdasarkan rekomendasi Komisi Pemilihan Umum mengenai hasil perolehan suara Partai Politik serta perolehan suara calon anggota legislatif dalam pemilu legislatif tanggal 9 April 2009. Kedua, pembentukan Fraksi. Pembentukan Fraksi ini dipimpin oleh Pimpinan Sementara DPRD Kota Surabaya yang terdiri dari 1 orang Ketua dan 1 orang Wakil Ketua dan berasal dari 2 Partai Politik yang berhasil mendapat kursi terbanyak pertama dan kedua di DPRD Kota Surabaya. Ketiga, penetapan rancangan peraturan tata tertib (tatib) dan pembentukan alat kelengkapan yang terdiri dari unsur: Pimpinan Definitif (1 orang Ketua dan 3 orang Wakil Ketua), Badan Musyawarah, Komisi, Badan Legislasi Daerah, Badan Anggaran, dan Badan Kehormatan. Penetapan atau pengesahan rancangan peraturan tata tertib (tatib) dan pembentukan alat kelengkapan dilakukan dalam rapat paripurna yang dipimpin oleh Pimpinan Definitif yang sebelumnya telah diresmikan dengan Surat Keputusan (SK) Gubernur Provinsi Jawa Timur.

Meski demikian, proses pembentukan alat kelengkapan DPRD Kota Surabaya periode 2009-2014 tidak berjalan lancar. Hal tersebut disebabkan oleh surat Menteri Dalam Negeri (Mendagri) nomor 161/3405/SJ tentang Pelaksanan Tugas dan Fungsi DPRD Provinsi/Kabupaten/Kota Masa Jabatan 2009-2014, yang turun setelah proses pembentukan alat kelengkapan DPRD Kota Surabaya berakhir. Pada dasarnya, surat Menteri Dalam Negeri tersebut selain bertujuan untuk menjelaskan Pasal 353 Ayat 3 
Undang-undang Nomor 27 Tahun 2009 Tentang MPR, DPR, DPD, dan DPRD, juga bermaksud untuk memberi kejelasan mengenai batasan kewenangan antara pimpinan defnitif dengan pimpinan sementara yang selama ini tidak pernah diatur secara tegas oleh Undang-undang dan Peraturan Pemerintah. Karena, keputusan suatu Menteri berfungsi untuk: ${ }^{39}$

1. Melakukan pengaturan secara umum dalam rangka menyelenggarakan kekuasaan pemerintahan sesuai dengan bidangnya.

2. Melakukan pengaturan lebih lanjut ketentuan yang ada dalam Keputsan Presiden. Sebab, fungsi ini merupakan pendelegasian dari Pasal 17 Ayat 1 UUD 1945.

3. Melakukan pengaturan lebih lanjut segala ketentuan yang ada di dalam Undang-undang, yang secara tegas menyebutnya. Sebab, Undang-undang ialah peraturan yang bersifat umum, sehingga diberlukan perangkat hukum lain yang diatur oleh Menteri yang bersangkutan untuk melaksanakannya.

4. Melakukan pengaturan lebih lanjut ketentuan segala yang ada di dalam Peraturan Pemerintah, yang secara tegas menyebutnya.

Dengan didasarkan surat Menteri Dalam Negeri di atas, maka dapat diketahui bahwa pimpinan sementara DPRD Kota Surabaya tidak memiliki kewenangan untuk mengesahkan rancangan peraturan tata tertib pembentukan alat kelengkapan DPRD Kota Surabaya periode 2009-2014. Selain itu, alat kelengkapan yang telah dibentuk dengan dipimpin oleh pimpinan sementara tersebut masih belum memiliki kekuatan hukum, sebab alat kelengkapan itu masih belum diresmikan Gubernur Provinsi Jawa Timur selaku pejabat yang telah ditetapkan Undang-undang Nomor 27 Tahun 2009 Tentang MPR, DPR, DPD, dan DPRD untuk meresmikan alat kelengkapan DPRD Kabupaten/Kota yang berada

39 Maria Farida Indrati, IImu Perundang-undangan, Dasar-dasar dan Pembentukannya, (Yogyakarta: Kanisius, 2002), I17-1 18. 
di Provinsi Jawa Timur. Sehingga, pembentukan ulang alat kelengkapan DPRD Kota Surabaya periode 2009-2014 itu tidak menyalahi asas non-retroactive (hukum tidak berlaku surut).

Menurut pandangan Figh Siyasâh, mekanisme pembentukan alat kelengkapan DPRD Kota Surabaya periode 2009-2014 yang didasarkan urutan jumlah perolehan kursi Partai Politik dengan berpedoman pada hasil pemilihan umum legislatif 9 April 2009 lalu memiliki kemiripan dengan mekanisme yang pernah digunakan oleh Nabi Muhammad SAW ketika mengangkat Zaid bin Haritsah, Ja'far bin Abu Thalib, dan Abdullah bin Rawahah menjadi komandan perang Mu'tah secara sekaligus melalui sistem berurutan. ${ }^{40}$ Mekanisme pengangkatan langsung dengan sistem berurutan itu bertujuan untuk mencegah timbulnya benih permusuhan dan konflik di internal umat muslim pada waktu itu. Melalui mekanisme pengangkatan secara langsung dengan sistem berurutan ini Nabi Muhammad SAW memberikan contoh mengenai cara atau upaya yang dapat dilakukan untuk menghindari terjadinya permusuhan atau konflik internal. Sebab, permusuhan ialah perbuatan tercela (munkar) karena dapat merusak persaudaraan dan persatuan yang telah lama terjalin.

Dengan menggunakan salah satu metode ijtihad, yakni metode qiyas, ${ }^{41}$ untuk mengkomparasikan mekanisme yang digunakan oleh DPRD Kota Surabaya di dalam membentuk susunan struktur alat kelengkapan DPRD Kota Surabaya periode 2009-2014 dengan mekanisme yang pernah digunakan oleh Nabi Muhammad SAW ketika mengangkat 3 komandan perang Mu'tah secara langsung dengan sistem berurutan, maka dapat diketahui bahwa mekanisme pembentukan alat kelengkapan DPRD Kota Surabaya periode 2009-2014 bertujuan untuk menghindari konflik atau permusuhan di internal DPRD Kota Surabaya. Selain itu,

${ }^{40}$ Imam Al-Mawardi, Al-Ahkam As-Sulthaniyyah, Penerjemah; Fadli Bahri (Jakarta: Darul Falah, 2006), I8-19.

${ }^{41}$ Qiyas ialah metode untuk mencari ilat hukum (landasan hukum) dengan cara menyamakan furu' (hal baru) dengan ushul (hal yang mendasar). 
mekanisme penetapan secara langsung dengan sistem berurutan itu dapat mencegah terjadinya money politics.

Kesesuaian antara mekanisme yang digunakan oleh DPRD Kota Surabaya di dalam membentuk susunan struktur alat kelengkapan DPRD Kota Surabaya periode 2009-2014 dengan mekanisme yang pernah digunakan oleh Nabi Muhammad SAW ketika mengangkat 3 orang komandan perang $\mathrm{Mu}^{\prime}$ tah secara langsung dengan sistem berurutan itu terletak kepada dampak yang dapat ditimbulkan, yakni konflik internal. Nabi Muhammad SAW sangat tidak menghendaki umat muslim pada waktu terlibat konflik internal yang diakibatkan adanya proses perebutan kekuasaan untuk menjadi komandan perang. Sedangkan dampak yang dapat ditimbulkan apabila pembentukan alat kelengkapan DPRD Kota Surabaya periode 2009-2014 tidak melalui mekanisme penetapan secara langsung melalui urutan jumlah perolehan kursi Partai Politik ialah terjadinya praktik money politics dalam proses penentuan pimpinan alat kelengkapan itu. Dampak dari adanya praktik money politics tersebut adalah konflik antar sesama anggota DPRD Kota Surabaya yang merasa tidak puas terhadap hasil pemilihan itu.

Dengan demikian, dapat diketahui bahwasannya mekanisme penetapan secara langsung dengan sistem berurutan yang digunakan oleh DPRD Kota Surabaya dalam membentuk alat kelengkapan periode 2009-2014 itu mencerminkan perbuatan amar ma'ruf nahi munkar. Dengan demikian, maka mekanisme penetapan secara langsung dengan sistem berurutan itu sesuai dengan ajaran Islam yang tertuang di dalam Surat At-Taubah Ayat 71, yang berbunyi:

"Dan orang-orang yang beriman, lelaki dan perempuan, sebahagiaan mereka (adalah) menjadi penolong bagi sebahagian yang lain. Mereka menyeruh (mengerjakan) yang ma'ruf, mencegah dari yang munkar, mendirikan sembahyang, menunaikan zakat, dan mereka taat kepada Allah. Mereka itu akan diberi rahmat oleh Allah.

\section{I $\mid \begin{aligned} & \text { al-Daulah } \\ & \text { Vol. 5. no.1. April } 2015\end{aligned}$}


Sesungguhnya Allah maha perkasa lagi maha bijaksana". (QS. At-Taubah: 71). ${ }^{42}$

Untuk terwujudnya kemaslahatan umat diperlukan adanya persatuan. Sebab, persatuan termasuk upaya mencegah terjadinya permusuhan atau konflik yang dapat menyebabkan kegagalan anggota DPRD Kota Surabaya periode 2009-2014 dalam mewujudkan aspirasi rakyat. Untuk itu, maka anggota DPRD Kota Surabaya periode 2009-2014 wajib menghindari segala perbuatan yang dapat menyebabkan terjadinya konflik, sebagaimana teruang Surat An-Nahl Ayat 90, yang artinya:

"Sesungguhnya Allah menyuruh (kamu) berlaku adil dan berbuat kebajikan, memberi kaum kerabat, dan Allah melarang dari perbuatan keji, kemungkaran dan permusuhan. Dia memberi pengajaran kepadamu agar kamu dapat mengambil pelajaran". (Q.S. An-Nahl: 90).43

Anggota DPRD Kota Surabaya periode 2009-2014 sebagai representasi dari Ahlul Halli wal Aqdi yang dipilih rakyat secara langsung melalui pemilihan umum dituntut untuk dapat menjadi tauladan dan memberikan pendidikan politik yang baik kepada rakyat dengan tidak menggunakan money politics dalam membentuk susunan alat kelengkapan atau struktur organisasi. Sebab, money politics dapat menimbulkan konflik internal dan merusak persatuan antar anggota DPRD Kota Surabaya. Dan hal itu akan menghambat kinerja dari anggota DPRD Kota Surabaya untuk mewujudkan kemaslahatan umat. Sebab, kemaslahatan umat tidak akan terwujud apabila anggota DPRD Kota Surabaya sibuk berkonflik untuk memperebutkan kekuasaan.

\section{Tinjauan Fiqh Siyasâh terhadap Penetapan Alat Kelengkapan} DPRD Kota Surabaya Periode 2009-2014

Dalam Islam, pemerintah (Khalifah) dan Ahlul Halli wal Aqdi bertugas untuk menyelenggarakan pemerintahan dengan

42 Departemen Agama Republik Indonesia, A/-Qur'an, 291.

43 Ibid, 4 I 5. 
didasarkan pada perundang-undangan yang dibuat oleh Ahlul Halli wal Aqdi dan dilaksankan oleh pemerintah. Kekuasaan untuk menyelenggarakan proses pemerintahan itu dilandasi oleh aspek formal normatif dan struktural normatif. Aspek formal normatif yang bertumpu pada Al-Qur'an maupun Sunnah Rasul tersebut menyebabkan adanya tugas untuk menjalankan pemerintahan dengan adil. Sedangkan, aspek struktural formatif dapat mengakibatkan:44

1. Distribusi atau pelimpahan kekuasan kepada Pemerintah Paerah. Dengan adanya pelimpahan kekuasaan ini Pemerintah Daerah dituntut untuk menjalankan proses pemerintahan sesuai dengan peraturan perundangundangan yang berlaku.

2. Distribusi atau pelimpahan kekuasaan Pemerintah Pusat kepada lembaga-lembaga yang berada dibawah naungannya secara langsung. Sehingga lembaga-lembaga itu dapat memberikan tugas-tugas tertentu kepada aparatnya yang ada didaerah.

Agar proses pemerintahan berjalan dengan baik, maka setiap Kepala Daerah (Gubernur, Walikota, dan Bupati) diberi kewenangan untuk melakukan pengawasan terhadap lembagalembaga yang lebih rendah tingkatannya. Pengawasan yang dapat dilakukan oleh Kepala Daerah itu meliputi: ${ }^{45}$

1. Meminta, menerima, serta mengusahakan keterangan atau bahan yang diperlukan, baik oleh Kepala Daerah maupun instansi pemerintahan daerah yang bersangkutan.

2. Melakukan atau menyuruh pejabat instansi pemerintahan daerah yang lain untuk melakukan penyelidikan atau pemeriksaan di tempat-tempat kerja (sidak).

3. Menerima dan mempelajari pengaduan.

${ }^{44}$ Abdul Mu'in Salim, Fiqh Siyasâh, Konsepsi Kekuasaan Politik Dalam Al-Qur'an, Jakarta: RajaGrafindo Persada, 1994), 302-304.

${ }^{45}$ C.S.T. Kansil dan Christine S.T. Kansil, Sistem Pemerintahan Indonesia, (Jakarta, Bumi Aksara, 2008), 155. 
4. Memanggil pejabat untuk dimintai keterangan yang diperlukan.

5. Menyarankan langkah-langkah, baik secara represif atau preventif terhadap segala bentuk pelanggaran kepada pejabat maupun instansi atau lembaga yang berwenang. Pengawasan secara represif berkaitan dengan penangguhan atau pembatalan putusan Peraturan Daerah yang bertentangan dengan kepentingan umum atau peraturan yang lebih tinggi. Sedangkan, langkah preventif merupakan tindakan yang mengharuskan agar seluruh Peraturan Daerah berlaku, jika sudah mendapatkan pengesahan dari:

a. Menteri Dalam Negeri, untuk seluruh Peraturan Daerah tingkat I.

b. Gubernur, untuk seluruh Peraturan Daerah tingkat II.

Sedangkan, aturan yang dipakai dalam menjalankan kekuasaan pemerintahan itu adalah dengan menegakkan keadilan serta menyampaikan amanat yang sebenar-benarnya, agar proses pemerintahan dapat berjalan baik sesuai perundang-undangan yang berlaku, sebagaimana terdapat dalam surat An-Nisa' Ayat 58 yang berbunyi:

"Sesungguhnya Allah menyuruh kamu menyampaikan amanat kepada yang berhak menerimanya, dan (menyuruh kamu) apabila menetapkan hukum diantara manusia supaya kamu menetapkan dengan adil. Sesungguhnya Allah memberi pengajaran yang sebaik-baiknya kepadamu. Sesungguhnya Allah maha mendengar lagi maha melihat". (Q.S. An-Nisa': 58). ${ }^{46}$

Dengan demikian dapat diketahui bahwasannya penangguhan yang dilakukan Gubernur Provinsi Jawa Timut terhadap hasil pembentukan alat kelengkapan DPRD Kota Surabaya periode 2009-2014 yang dipimpin oleh pimpinan sementara itu ialah upaya untuk mencegah terjadinya kekeliruan

${ }^{46}$ Departemen Agama Republik Indonesia, Al-Qur'an, 128. 
dalam melaksanakan amanat konstitusi atau Undang-undang Nomor 27 Tahun 2009 Tentang MPR, DPR, DPD, dan DPRD.

Keabsahan alat kelengkapan DPRD Kota Surabaya periode 2009-2014 sangat tergantung kepada proses pembentukan yang dilakukan oleh DPRD Kota Surabaya itu sendiri. Hal tersebut mengacu pada sebuah hadis yang berbunyi: "antum a'lamu biumuuri dun-yaakum" yang berarti bahwa kalian lebih tahu mengenai urusan dunia kalian. Melalui pendekatan ini Islam berupaya untuk mengarahkan agar mekanisme pembentukan alat kelengkapan DPRD Kota Surabaya periode 2009-2014 berdasarkn urutan jumlah perolehan kursi Partai Politik dapat berfungsi untuk mencegah money politics dan konflik antar sesama anggota DPRD Kota Surabaya.

Untuk itu, maka seluruh anggota DPRD Kota Surabaya periode 2009-2014 wajib untuk mentaati dan menjalankan perintah Gubernur Provinsi Jawa Timur yang didasarkan kepada surat edaran Menteri Dalam Negeri Nomor 161/3405/SJ Tentang Pelaksanaan Tugas dan Fungsi DPRD Provinsi/Kabupaten/Kota Masa Jabatan 2009-2014 dengan cara menetapkan kembali rancangan peraturan tata tertib (tatib) dengan dipimpin oleh Pimpinan Definitif yang telah diresmikan dengan surat keputusan atau SK Gubernur Provinsi Jawa Timur.

\section{Penutup}

Alat kelengkapan DPRD Kota Surabaya periode 2009-2014, yang terdiri dari: Pimpinan (1 Ketua dan 3 Wakil Ketua), Badan Musyawarah, Komisi, Badan Legislasi Daerah, Badan Anggaran, dan Badan Kehormatan dibentuk dengan mengikuti urutan jumlah perolehan kursi partai politik yang berpedoman pada hasil pemilu legislatif tanggal 9 April 2009 lalu.

Dalam tinjauan Fiqh Siyasâh, mekanisme pembentukan alat kelengkapan DPRD Kota Surabaya periode 2009-2014 berdasarkan urutan jumlah perolehan kursi Partai Politik dengan mengikuti hasil pemilu legislatif tanggal 9 April 2009 lalu dapat mencegah

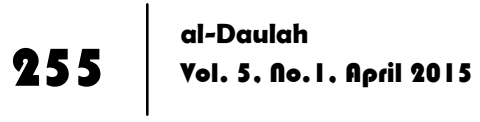


terjadinya money politics dan konflik internal diantara sesama anggota DPRD Kota Surabaya.

\section{Daftar Pustaka}

Cipto, Bambang. Dewan Perwakilan Rakyat; Dalam Pemerintahan Era Modern dan Industrial. Jakarta: PT. Raja Grafindo Persada, 1995.

Departemen Agama Republik Indonesia. Al-Qur'an Dan Terjemahnya. Bandung: PT. Sygma Examedia Arkenleema, 2012.

Fatwa, A. M. Melanjutkan Reformasi Membangun Demokrasi Dalam Jejak Langkah Parlemen Indonesia Periode 1999-2004. Jakarta, PT RajaGrafindo Persada, 2004.

Hanik, Eka Naila. Kepala Sub Bagian rapat dan Risalah DPRD Kota Surabaya, Wawancara, 5 April 2010 pukul 09.00 WIB di Sekretariat DPRD Kota Surabaya.

Indrati, Maria Farida. Ilmu Perundang-undangan, Dasar-dasar dan Pembentukannya. Yogyakarta: Kanisius, 2002.

Kansil, C.S.T. Pokok-pokok Pemerintahan di Daerah. Jakarta: Rineka Cipta, 1991.

-------. Sistem Pemerintahan Indonesia. Jakarta: Bumi Aksara, 2008.

Limantoro, Irwanto. Ketua Fraksi Demokrat DPRD Kota Surabaya periode 2009-2014, Wawancara, 18 Januari 2010 pukul 09.00 WIB di ruang Fraksi Demokrat.

Mawardi (al-), Imam. Al-Ahkam As-Sulthaniyyah, Penerjemah; Fadli Bahri. Jakarta: Darul Falah, 2006.

Salim, Abdul Mu'in. Figh Siyasâh, Konsepsi Kekuasaan Politik Dalam Al-Qur'an. Jakarta: RajaGrafindo Persada, 1994.

Sanit, Arbi. Partai, Pemilu, dan Demokrasi. Jakarta: Pustaka Pelajar, 1997.

. Perwakilan Politik di Indonesia. Jakarta: Rajawali Press, 1985.

Sirajuddin, dkk. Parlemen Lokal DPRD Peran dan Fungsi dalam Dinamika Otonomi Daerah. t.t.: Setara Press, 2009. 
Jawa Pos, 10 September 2009

Jawa Pos, 12 September 2009

Jawa Pos, 16 September 2009

Jawa Pos, 17 September 2009

Jawa Pos, 25 September 2009

Jawa Pos, 27 September 2009

Jawa Pos, 7 Oktober 2009

www.dprdsurabaya.go.id, 28 Februari 2010.

www.kpusurabaya.go.id, diakses 28 Februari 2010. 